\title{
Antitumoral potency of methanolic extract from Nitraria retusa leaves via its immunomodulatory effect
}

Jihed Boubaker ${ }^{1,2,3^{*}}$, Fadwa Chaabane ${ }^{1,2}$, Ahmed Bedoui ${ }^{1,2}$, Rihab Aloui ${ }^{3}$, Besma Ben Ahmed ${ }^{3}$, Kamel Ghedira² and Leila Chekir-Ghedira ${ }^{1,2}$

\begin{abstract}
Background: The purpose of this study was to assess the antitumoral effect of the methanol extract (MeOH) from Nitraria retusa leaves and to investigate its immunomodulatory activity that mediated the prevention of tumor progression in tumor-bearing mice.

Methods: Balb/c mice weighing 18-20 g were subcutaneously implanted with B16-F10 cells then injected intraperitoneally, 7 days later with $(200 \mathrm{mg} / \mathrm{kg}$ bw) of $\mathrm{MeOH}$ extract, for 21 days. After euthanization on day 21, the tumors were weighed. Lymphocyte proliferation, cytotoxic T lymphocyte $(\mathrm{CTL})$ and NK activity were evaluated using the MTT assay. Macrophage phagocytosis was studied by measuring their lysosomal activity and nitric oxide production.

Results: The methanol extract inhibited significantly the growth of the implanted tumor, and increased remarkably splenocyte proliferation as well as NK and CTL activities, in tumor-bearing mice. It also promoted lysosomal activity of treated animal macrophages.
\end{abstract}

Conclusion: Our findings suggest that antitumoral effect of $\mathrm{MeOH}$ extract is related with to immunomodulatory activity.

Keywords: Nitraria retusa, Melanoma, Antitumor, Immunomodulatory, Natural killer, Splenocyte

\section{Résumé}

Introduction: Le but de cette étude est d'évaluer l'effet antitumoral de l'extrait méthanolique $(\mathrm{MeOH})$ issue des feuilles de N. retusa via son potentiel immunomodulateur et sa capacité à prévenir la progression tumoral chez des souris porteuses de tumeurs.

Méthodes: Pour cette étude, nous avons implanté par voie sous-cutanée, chez des souris Balb/c de 18 à $20 \mathrm{~g}$, des cellules B16-F10. Après apparition de la tumeur, au bout de 7jours de l'injection de B16-F10, nous avons entamé un traitement par injection intrapéritonéale de $200 \mathrm{mg} / \mathrm{kg}$ de poids corporel, d'extrait MeOH, et ce durant 21 jours. Les animaux sont euthanasiés au $21^{\text {ème }}$ jour, et les tumeurs sont pesées. La prolifération des splénocytes et des lymphocytes T cytotoxiques (CTL) à été évalué à l'aide du test au MTT. L'évaluation de l'activité NK à également été effectuée à l'aide du par le même test. Dans un second volet, nous avons étudié l'activité phagocytaire des macrophages en évaluant leur activité lysosomale et la production d'oxyde nitrique.

Résultats: L'extrait MeOH révèle, un fort potentiel inhibiteur de la croissance de la tumeur transplantée, une augmentation de façon remarquable de la prolifération des splénocytes ainsi qu'une forte induction des activités

\footnotetext{
*Correspondence: jihed.boubaker@yahoo.fr

${ }^{2}$ Unity of Bioactive Natural Substances and Biotechnology, Faculty

of Pharmacy, University of Monastir, Rue Avicenne, Monastir 5000, Tunisia

Full list of author information is available at the end of the article
} 
NK et CTL chez des souris porteuses de tumeurs. Aussi l'extrait a considérablement induit l'activité phagocytaire des macrophages en augmentant leur activité lysosomale ainsi que la production de monoxide d'azote, par ces cellules.

Conclusion: Nos résultats suggèrent fortement que l'effet antitumoral de l'extrait méthanolique passe par son potentiel immunomodulatrice.

\section{Background}

Melanoma is the most aggressive form of skin cancer with an annual incidence consistently increasing worldwide [1]. Treatment options are limited for advanced stage patients and new therapies showing success in only a subset of patients [2].

The immune system is capable of recognizing melanoma tumors, and patients readily develop melanomaspecific $\mathrm{T}$ cell responses [3]. However, in most cases, these immune responses ultimately fail to eradicate established melanoma tumors [4].

Immunomodulation through natural or synthetic substances may be considered an alternative for the prevention and cure of neoplastic diseases [5]. The enhancement of host immune response has been recognized as a possible means of inhibiting tumor growth without harming the host [6]. Therefore, it is very important to investigate novel antitumor substances with improving immunity potential.

Nitraria retusa is commonly used in Tunisian traditional medicine to treat stomach pain, ulcers and gastritis. However, there are no studies regarding the antitumoral or immunomodulatory activities of $N$. retusa. Recently, we have demonstrated that methanol extract from $N$. retusa leaves exhibited antiproliferative potential against cancer cell lines in vitro [7]. Moreover, apoptotic effect of this plant has been carried out in some cancerous cell lines $[7,8]$. However, there are no studies regarding the antitumoral or immunomodulatory activities of this plant.

Thus, we evaluated in this study the melanoma growth inhibiting capacity, of the $\mathrm{MeOH}$ extract against B16-F10 mouse melanoma cells, implanted in Balb/c mice in vivo. In addition, we investigated the potency of the tested extract on host immune responses of tumor-bearing mice.

This study show, for the first time, that methanolic extract of $N$. retusa leaves exert in vivo antitumoral and immunomodulatory activities.

\section{Results}

Phytochemical study of methanol extract from N. retusa leaves

As described in our previous study [7], methanol $(\mathrm{MeOH})$ extract exhibited the highest quantities of flavonoids and polyphenols respectively $(146.52 \mu \mathrm{g} / \mathrm{ml}$ concentration equivalent quercetin and $30 \mu \mathrm{g} / \mathrm{ml}$ concentration equivalent gallic acid).

\section{Cytotoxic effect on B16-F10 cell line}

We have examined the effect of different concentrations (ranging from 10 to $1000 \mu \mathrm{g} / \mathrm{ml}$ ) of $(\mathrm{MeOH})$ extract on B16-F10 cell growth using the MTT assay. The results of this assay are reported in (Fig. 1). $\mathrm{MeOH}$ extract inhibited the malignant tested cell growth.

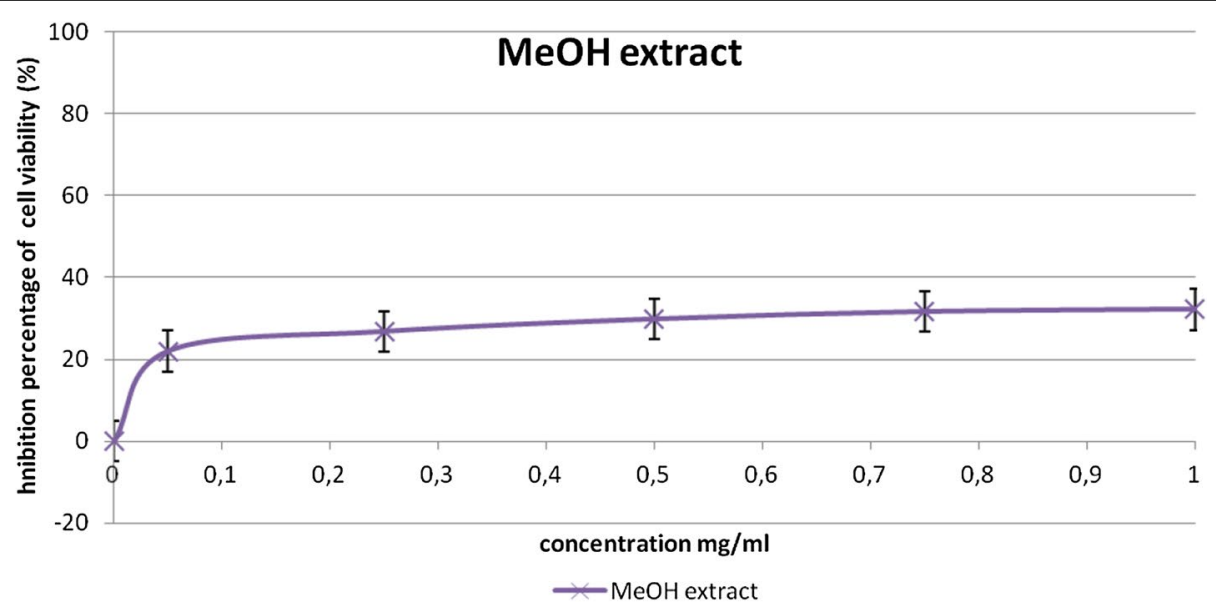

Fig. 1 Anti-proliferative effect of methanol extract of Nitraria retusa leaf on B16-F10 melanoma cells. Values represent the mean \pm SD of three separate experiments 


\section{Acute toxicity}

No mortality was recorded in the group of animals treated with the $\mathrm{MeOH}$ extract at $200 \mathrm{mg} / \mathrm{kg} \mathrm{BW}$.

\section{Effect of methanol extract on weight and volume of tumor} Our results suggest that $(\mathrm{MeOH})$ extract significantly suppresses growth of tumor cells in the tumor-bearing mice. The average tumor size in $(\mathrm{MeOH})$ extract-treated group was significantly smaller than that in the positive control group (Fig. 2). The inhibition of tumor volume reached $95.19 \%$. Consistent with this result, the average tumor weight after the administration to animals of the extract, was significantly lower than in positive control (animal with tumor) (PC). The inhibition percentage reached $88.95 \%$ (Fig. 3).

\section{Effect of methanol extract on splenocytes proliferation}

The results showed that spontaneous proliferative capacity of splenic lymphocytes decreased in positive control mice (PC) compared to healthy mice (NC). Proliferative capacities decreased, after tumor induction, to $22.94 \%$. Treatment with methanol extract $(200 \mathrm{mg} / \mathrm{kg}$ b.w $)$ significantly restored the proliferation of splenic lymphocytes. The percentage of stimulation reached $64.2 \%$ (Fig. 4).

\section{Effect of methanol extract on NK cell activity}

The results of this assay were reported in Fig. 5. In fact, NK activity increases from $21.89 \%$ in healthy mice to $48.66 \%$ in the tumor-bearing (PC) mice. Treatment with

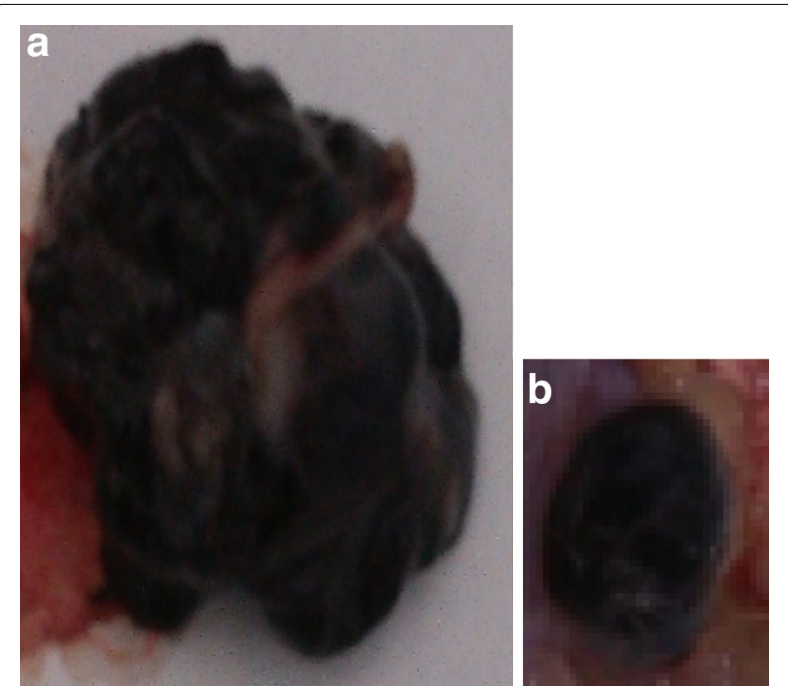

Fig. 2 Inhibitory effect of $N$. retusa methanol extract on subcutaneous melanoma in Balb/c mice. Mice were sacrificed and then analyzed for representative macroscopic photographs of melanoma tumor weight and volume were determined. a Animal bearing tumor (positive control) (PC), b from animals bearing tumor and treated with $\mathrm{MeOH}$ extract at $200 \mathrm{mg} / \mathrm{kg}$ b.w
$(\mathrm{MeOH})$ extract increased the NK activity by $136.27 \%$ in tumor-injected mice, revealing thus an induction of this cell defense system.

\section{Effect of methanol extract on CTL activity}

Spleen cells from the experimental mice were assessed for specific cytotoxic activity against B16F10 melanoma cells (Fig. 6). Data reported in Fig. 5 showed that the presence of the tumor, significantly suppressed cytotoxic capacities of CTL. The CTL activity decreased from $27.33 \%$ in the group of healthy mice (NC) to $13.77 \%$ in the tumorbearing mice group (PC). Treatment with $\mathrm{MeOH}$ extract allows rising of CTL activity, in the tumor-injected mice, to $54.64 \%$ on days 21 .

\section{Effect of methanol extract on peritoneal macrophage lysosomal activity}

The activity in macrophages harvested from tumorinjected mice (PC) decreased significantly (by $65.87 \%$ ) when compared to untreated animals.Whereas lysosomal activity of macrophages obtained from $\mathrm{MeOH}$ extract treated tumor bearing mice $(200 \mathrm{mg} / \mathrm{kg} \mathrm{b.w}$ ) increased by $255.37 \%$ when compared to that of untreated mice cells (Fig. 7).

\section{Effect of methanol extract on peritoneal macrophage nitric oxide production}

Macrophages isolated from mice treated with $\mathrm{MeOH}$ extract $(200 \mathrm{mg} / \mathrm{kg} \mathrm{b.w})$ for $24 \mathrm{~h}$, display a significant increase in NO production. In fact, NO concentration rises from $14.38 \mu \mathrm{M}$ (PC: positive control) to $23.35 \mu \mathrm{M}$ (macrophage treated mice) Fig. 8

\section{Discussion}

The number of new cancer cases each year is projected to rise worldwide by about $70 \%$ by 2030 due to demographic changes alone, with the largest increases in the lower-income countries. Lung, liver, colorectal and breast cancers are the most commonly diagnosed in males and females respectively, and these cancers also represent the most frequent types of cancer related deaths. Thus, medical advances in disease treatment are an issue at a later stage and should be made available globally [9].

Our study revealed that $\mathrm{MeOH}$ extract inhibits melanoma cell proliferation in a dose dependent manner. This cytotoxicity may be ascribed to the presence of specific components such as polyphenols and flavonoids [7], as far as. They were the main constituents of the tested extract. In addition, Martinez et al. and Yanes et al. [10, 11] reported previously then antiproliferative activity of such compounds against melanoma cells. Our aim was to investigate alternative phytotherapy solutions to current anticancer treatments and preventing cancer 

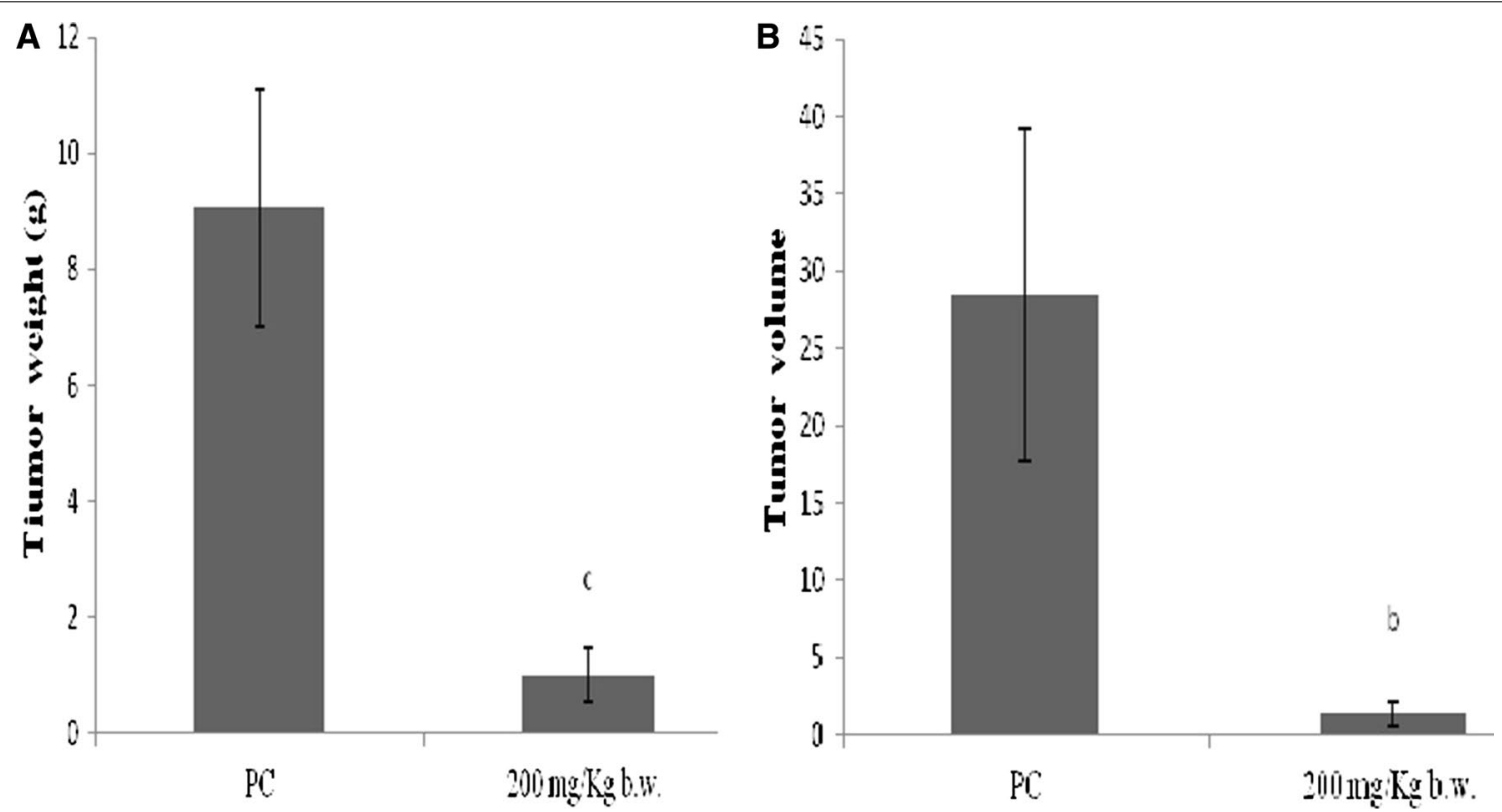

Fig. 3 Effect of methanol extract from N. retusa on B16F10 melanoma growth in Balb/C mice. A Effect of tested extract on tumor weight, B effect of tested extract on tumor volume. All data shown are mean $( \pm S D)$ percent inhibition values, and are representative of two independent experiments. (b) $P<0.01$ significantly different from that of mice with melanoma ( $P C$ ). (c) $P<0.001$ significantly different from that of mice with melanoma (PC)

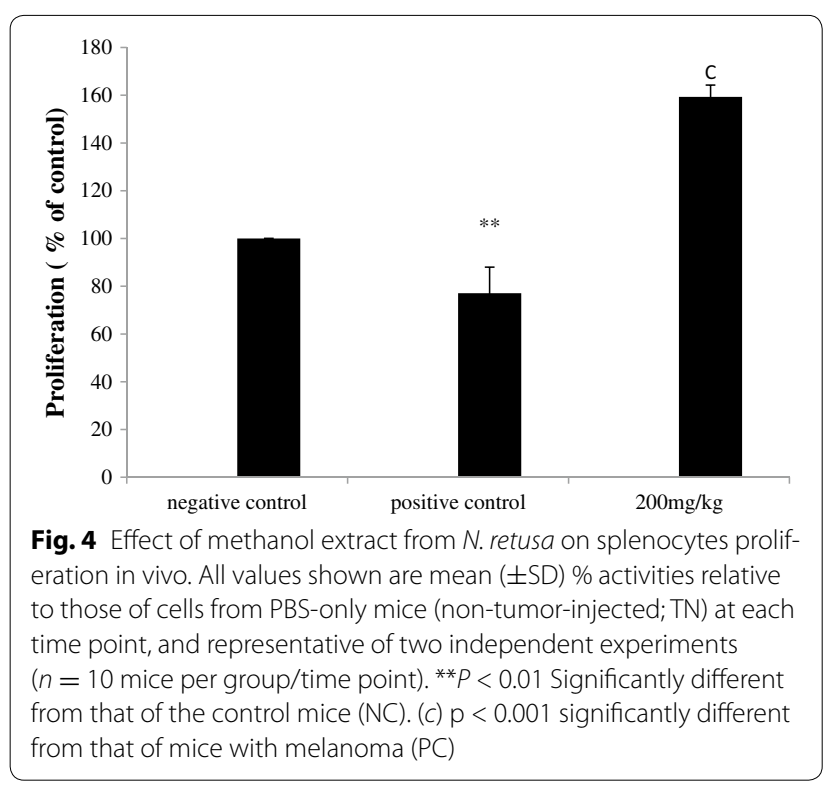

development. Thus we demonstrated that $N$. retusa leaf extract exhibits an anti-tumoral potency in melanomabearing mice. Despite the fact that the mechanisms underlying $\mathrm{MeOH}$ extract anti-tumor potency may be complex, our data showed that this potency was most likely related to the regulation of the immune responses. Host immunity is involved in the development and progression of malignant disease. Some studies had reported that anti-tumor potencies of plant extracts should involve

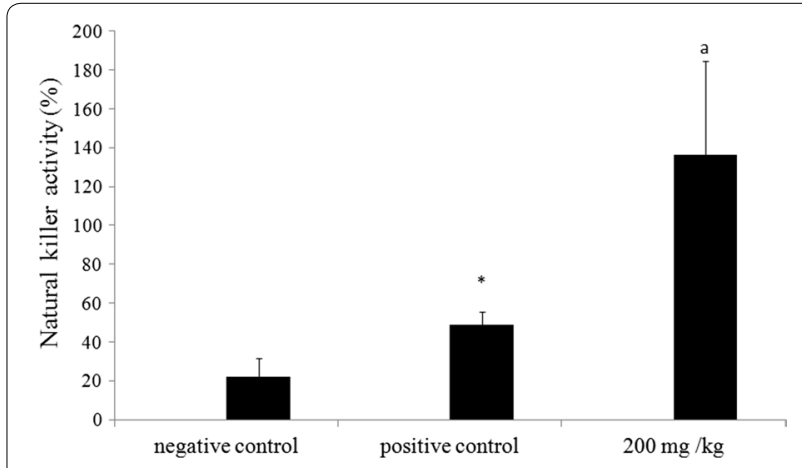

Fig. 5 Effect of methanol extract from N. retusa on NK cell activity in vivo. All data shown are mean ( \pm SD) \% NK activity, and are representative of two independent experiments ( $n=10$ mice per group/ time point). ${ }^{*} P<0.05$ significantly different from that of the control mice (NC). (a) $P<0.05$ significantly different from that of mice with melanoma $(P C)$

the enhancement of the main executors of the immune defense cells, such as lymphocytes and macrophages [12]. Thus, T cells can assign tumor cells directly or can act indirectly by releasing cytokines that amplify cytotoxic $\mathrm{T}$ lymphocyte responses or activate NK cells and macrophages [13]. In fact, CTL and NK cells are rich in cytoplasmic granules. Following degranulation, the cells produce specific biologically active substances, which have a cytotoxic activity on target cells. These granules contain perforin, granzymes, granulysin and other 


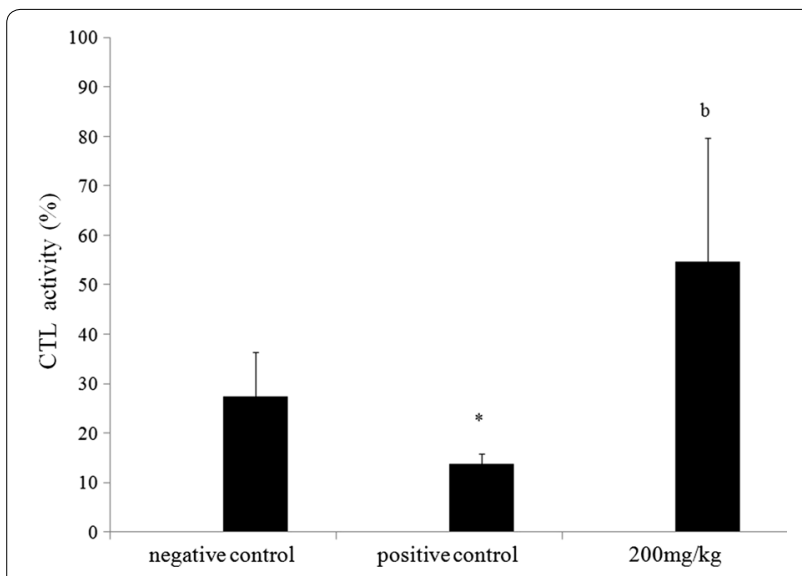

Fig. 6 Effect of methanol extract from $N$. retusa on cytotoxic T-lymphocyte (CTL) activity in vivo. All data shown are mean ( \pm SD) \% killing activity, and are representative of two independent experiments ( $n=10$ mice per group/time point). ${ }^{*} P<0.05$ significantly different from that of the control mice (NC). (b) $P<0.01$ significantly different from that of mice with melanoma $(P C)$

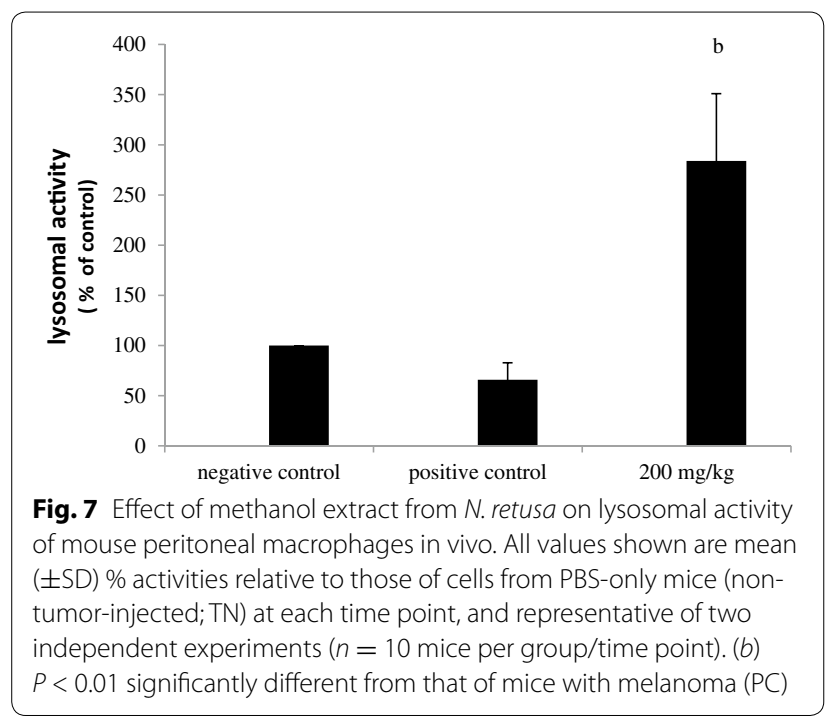

effector molecules involved in the anti-tumor potency, as well as some unidentified components [14, 15].

Our study revealed that treatment of tumor-bearing mice with $\mathrm{MeOH}$ extract increases their NK cells activity of. In fact, NK cell are known to be the major mediators of the innate anti-tumor immune responses; they eradicate tumors by recognizing stress-inducible ligands on tumors cells and execute tumor cells with perforin and granzyme in vivo [16]. NK cells stamp out solid tumors by apoptosis [16].

The proliferation of splenocytes induced by $\mathrm{MeOH}$ extract in tumor bearing mice could be attributed to flavonoids and polyphenols [17], a class of agents already

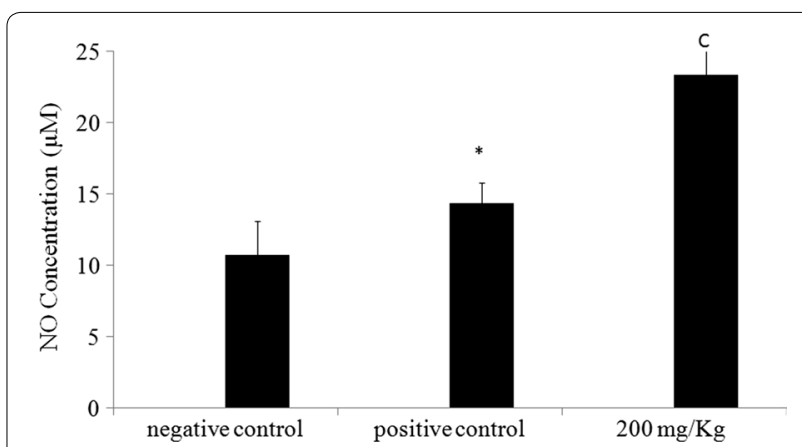

Fig. 8 Effect of the methanol extract from N. retusa on production of the nitrite by mouse peritoneal macrophages in vivo. Data shown are mean $( \pm S D)$ percentage of NO production from three independent experiments. ${ }^{*} \mathrm{P}<0.05$ significantly different from that of the control mice (NC). (c) $P<0.001$ significantly different from that of mice with melanoma (PC)

known to be mechanistically active on immune system [18] and to modulate the immune activity [19].

One of the most important non-specific immune activities in situ, is phagocytosis performed by macrophages (as well as by other types of leukocytes). Phagocytosis is accompanied by the release of lysosomal enzymes like acid phosphatase (AP) used for the killing and digesting of microbial pathogens. The higher AP activity, the greater the phagocytic stimulation and intracellular killing capacity [20]. Our study showed that the tested extract increases significantly cellular lysosomal enzyme activity. This is most likely attributed to the flavonoid, tannin and polyphenol contents of the tested extract, which could be responsible for this particular immunomodulatory potency [18].

Macrophage phagocytosis is also assigned by the liberation of free radicals such as nitric oxide (NO), involved in pathogen killing [21]. We showed that $\mathrm{MeOH}$ extract induces NO synthesis, by peritoneal macrophages, reflecting phagocytic stimulation; as such, the extract could act as an immunostimulant of innate immunity. Many plants have been shown to affect lysosomal activity and NO synthase activity in macrophages [22, 23]. This result could be ascribed to the presence of polyphenols and flavonoids in methanol extract. Polyphenols are known to enhance the nitroblue tetrazolium (NBT) reducing activity of macrophages [24], to activate morphological change (spreading) of peritoneal macrophages, and to induce various antitumor cytokines including tumor necrosis factor (TNF), interleukin (IL)-1 [25], and nitric oxide [26].

It is noteworthy that development of melanoma is associated with immune suppression [27]. This is in 
accordance with our findings, which demonstrate a decrease in CTL activity in mice bearing-tumor but not those treated with the tested extract.

On the other hand, we observed a significant proapoptotic activity of the methanol extract against several as tumoral cell lines in vitro K562 [7], TK6 and B16f10 (data not shown), we assessed the ability of the extract to inhibit cell proliferation in vivo. This study showed that $200 \mathrm{mg} / \mathrm{kg}$ bw of $\mathrm{MeOH}$ extract reduced tumor size and weight. Such results were in agreement with findings of other researchers who reported the in vivo anti-tumoral activity of some plant extracts [12].

\section{Conclusion}

Our results indicate for the first time, a significant antitumor effect of $N$. retusa leaf extract. This property is associated to immunomodulating effect upon splenocytes, NK cells and macrophages. However further characterization of bioactive compounds in the crude extract is warranted in future studies. The pharmacologically active ingredients and the signaling pathways involved in the antitumor activity also remain to be further elucidated.

\section{Methods}

\section{Plant material}

Leaves of $N$. retusa were collected from saline soils in Sahline, a region situated in mid-Tunisia, in December 2006. Their identification was done by Pr. M. Cheieb (Department of Botany, Faculty of Sciences, University of Sfax, Tunisia), according to the Flora of Tunisia [28, 29]. A voucher specimen (N.r-12.06) has been kept in our laboratory for future reference. The leaves were hade dried, powdered, and stored in a tightly closed container for further use.

\section{Preparation of methanolic extract}

Three hundred and fifty grams of powder, from dried leaves, were sequentially extracted in a Soxhlet apparatus (6 h) (AM Glassware, Aberdeen, Scotland, United Kingdom) with hexane, chloroform, ethyl acetate and methanol solvents. We obtained the correspondent extracts for each solvent. Hexane (Hex), chloroform $(\mathrm{Chl})$ and methanol $(\mathrm{MeOH})$ extracts, with different polarities, were concentrated to dryness and the residues were kept at $4{ }^{\circ} \mathrm{C}$. Then, each extract was resuspended in dimethyl sulfoxide solvent (DMSO). Plant materials were screened for the presence of tannins, flavonoids, coumarins and sterols using the methods previously described by Boubaker, et al. [30]. Amongst these extracts, only the methanolic one was used in the evaluation of the in vivo antitumoral and immumodulatory effects.

\section{Cell line and culture}

The B16F10 melanoma line was obtained from American Type Culture Collection (ATCC, Manassas, VA, USA) and grown at $37{ }^{\circ} \mathrm{C}$ in a humidified incubator with $5 \% \mathrm{CO}_{2}$ at $37{ }^{\circ} \mathrm{C}$. The cells were cultured in RPMI-1640 medium supplemented with $10 \%(\mathrm{v} / \mathrm{v})$ fetal calf serum (FCS, Biowhitaker, Lonza, Belgium), $2 \mathrm{mM}$ glutamine, $1 \%$ NEA (100X), $1 \%$ sodium pyruvate $100 \mathrm{mM}$ (complete RPMI).

\section{Assay for cytotoxic activity}

Cytotoxicity of $N$. retusa extracts against B16F10 cells was estimated by the 3-(4,5-dimethylthiazol-2-yl)-2,5-diphenyltetrazolium bromide (MTT) assay, based on the reduction of the MTT by mitochondrial dehydrogenases in viable cells. The resulting blue formazan product is measured spectrophotometrically [31] Cells were seeded in a 96-well plate at a concentration of $5 \times 10^{3}$ cells/well and incubated at $37{ }^{\circ} \mathrm{C}$ for $24 \mathrm{~h}$ in a $5 \% \mathrm{CO}_{2}$ enriched atmosphere. The extract was firstly dissolved in $1 \%$ DMSO, then in the cell growth medium. Cells were incubated again at $37^{\circ} \mathrm{C}$ for $48 \mathrm{~h}$ with each of the tested extract at concentrations ranging from 10 to $1000 \mu \mathrm{g} /$ $\mathrm{ml}$. Next, the medium was removed and cells in each well were incubated with $50 \mu \mathrm{l}$ of MTT solution $(5 \mathrm{mg} / \mathrm{ml})$ at $37^{\circ} \mathrm{C}$ for $4 \mathrm{~h}$. MTT solution was then discarded and $50 \mu \mathrm{l}$ of $100 \%$ DMSO were added to dissolve the insoluble formazan crystal. The optical density was measured at $540 \mathrm{~nm}$. Each drug concentration was tested in triplicate.

The cytotoxic effects of the extract was estimated in terms of cell population growth inhibition percentage and expressed as $\mathrm{IC}_{50}$ which is the concentration of extract that reduces the absorbance of the treated cells by $50 \%$ with reference to the control (cells treated with DMSO). The $\mathrm{IC}_{50}$ value was graphically obtained from the dose-response curves.

\section{Experimental animals}

Specific pathogen-free Balb/c mice (6-8 week-old males, 20-25 g) were obtained from the Pasteur Institute (Tunis, Tunisia). The animals were housed in polypropylene cages with stainless steel grill tops and provided with bedding of clean paddy husk. The animals were acclimatized to laboratory conditions for one week prior to treatment. All mice were housed under standard conditions of temperature $\left(25^{\circ} \mathrm{C}\right)$, humidity $(60 \%)$, and light (12-h light/dark) in an accredited pathogen-free facility. The mice were fed with standard laboratory pelleted feed. All animal experiments were performed in accordance with the guidelines for the care and use of laboratory animals published by the US National Institutes of Health. The study protocol was approved by the Ethics Committee of the University Hospital Fattouma-Bourguiba of Monastir, Tunisia. 


\section{Subcutaneous melanoma model in vivo treatment}

Mice were separated into three experimental groups ( $\mathrm{n}=60$; two separate studies using $\mathrm{n}=10$ /group): mice in the first group were treated with intraperitoneal injection of $\mathrm{MeOH}$ at $200 \mathrm{mg} / \mathrm{kg} \mathrm{BW}$ starting immediately after seven days of a single subcutaneous (SC) injection of $2 \times 10^{6}$ viable B16F10 tumor cells into their right hind leg (thigh) on Day 0. The second group was comprised of B16F10-injected mice that were treated only with PBS (PC: positive control) throughout the post-injection period. The last group (NC: negative control) - 'healthy mice'-received no tumor cells but received injections of PBS only in the post-injection period. The processing time of treatment period was for 21 days and every 2 days.

On Day 21, all mice were weighed and sacrificed. Solid tumors were collected and weighed, the longest and shortest diameters of tumors were measured with a vernier caliper and the tumor volume was determined according to established procedure [32]: Tumor volume $\left(\mathrm{mm}^{3}\right)=\left(\mathrm{L} \times \mathrm{W}^{2}\right) \times 0.5$ and then the inhibitory rate against tumor growth was calculated as $(\%)=[(\mathrm{PC}-\mathrm{Trt}) / \mathrm{PC}] \times 100 \%$, where $\mathrm{PC}$ is the average tumor weight in the tumor control mice ("PC" group above) and Trt is the weight in mice that had received methanolic extract.

\section{Acute toxicity}

For acute toxicity, mice were divided into two groups of six animals each. The first group served as a control and received only the vehicle solution, while the second group was treated by intraperitoneal injection (i.p) with dose of $200 \mathrm{mg} / \mathrm{kg}$ b.w. of $\mathrm{MeOH}$ extract.

\section{Splenocytes proliferation assay}

Mice were killed on day 21, and the spleen of each mouse was isolated aseptically and minced using a sterile forceps. The splenocytes were then centrifuged $(1500 \mathrm{rpm}$, $10 \mathrm{~min}$ ) and any red blood cells present lysed by resuspending the pellet in lysing buffer $\left(144 \mathrm{mM} \mathrm{NH}_{4} \mathrm{Cl}\right.$, $1.7 \mathrm{mM}$ Tris-Base) and placing on ice for $10 \mathrm{~min}$. Cells were then washed twice with PBS and then re-suspended in complete RPMI. Splenocytes proliferation assays were performed by using the MTT method. Splenocytes suspensions in complete RPMI $\left(5 \times 10^{5}\right.$ cells/well $)$ were incubated in 96-well plates for $48 \mathrm{~h}$ at $37^{\circ} \mathrm{C}$. Thereafter, the plates were centrifuged at $1500 \mathrm{rpm}$ for $10 \mathrm{~min}$, then each cell pellet was resuspended in $50 \mu \mathrm{l}$ MTT $(5 \mathrm{mg} / \mathrm{ml})$ in RPMI. The plate was then incubated a further $2 \mathrm{~h}$ at $37^{\circ} \mathrm{C}$ before the plates were centrifuged again, the MTT solution in each well was removed, and $100 \mu \mathrm{l}$ DMSO were added to each well. Percentage proliferation was calculated as:

$$
\begin{aligned}
& \text { Proliferation }(\%) \\
& \quad=100 \times(\mathrm{OD} \text { sample }-\mathrm{OD} \mathrm{NC}) / \mathrm{OD} \mathrm{NC})
\end{aligned}
$$

[33].

\section{Cytotoxic activity of natural killer (NK) cells}

Splenocytes isolated from each mouse were incubated with K562 cells. Briefly, splenocytes $\left(5 \times 10^{6}\right.$ cells/ well) (effector cell) were seeded in the well with the K562 cells $\left(5 \times 10^{4}\right.$ cells/well) (targeted cell). The plates were incubated at $37{ }^{\circ} \mathrm{C}$ with $5 \% \mathrm{CO}_{2}$ for $4 \mathrm{~h}$, and $50 \mu \mathrm{l}$ MTT solution $(5 \mathrm{mg} / \mathrm{ml})$ were added to each well. The plate were incubated a further $2 \mathrm{~h}$ and subjected to the protocols outlined above to assess formazan formation. NK cell activity was calculated as: NK activity $(\%)=100 \times(\mathrm{ODT}-(\mathrm{ODS}-\mathrm{ODE})) / \mathrm{ODT})$ where ODT, optical density value of target cells control, ODS, optical density value of test sample, ODE, optical density value of effector cells control [34]

\section{Assay of cytotoxic T-lymphocyte (CTL) activity}

Briefly, B16-F10 cells and isolated splenocytes were used as target and effector cells, respectively. The assay was performed as outlined above for the NK assay except that cells were incubated for $24 \mathrm{~h} .50 \mu \mathrm{l}$ MTT solution $(5 \mathrm{mg} /$ $\mathrm{ml}$ ) were added to each well and the plate was incubated a further $2 \mathrm{~h}$ and subjected to the protocols outlined above to assess formazan formation. The percentage of target cells killed was determined as in the NK assay:

$$
\begin{aligned}
& \text { CTL activity (\%) } \\
& \quad=100 \times(\mathrm{ODT}-(\mathrm{ODS}-\mathrm{ODE})) / \mathrm{ODT},
\end{aligned}
$$

where ODT, optical density value of target cells control, ODS, optical density value of test sample, ODE, optical density value of effector cells control.

\section{Cellular lysosomal enzyme activity}

Peritoneal macrophages were obtained after intraperitoneal injection of $5 \mathrm{ml}$ sterile PBS, and withdrawal of the fluid. Obtained cells were washed twice by PBS and re-suspended in complete RPMI 1640; cell viability was assessed via trypan blue exclusion. One hundred $\mu \mathrm{l}$ of the macrophage cell suspension $\left(6 \times 10^{6}\right.$ cells $\left./ \mathrm{ml}\right)$ were seeded in 96 flat-botton well plates treated with different concentrations of extract and incubated for $24 \mathrm{~h}$ at $37{ }^{\circ} \mathrm{C}$, under a humid atmosphere and at $5 \% \mathrm{CO}_{2}$. The adherent cells are taken up in $20 \mu \mathrm{l}$ Triton X-100 (1\%), $10 \mu \mathrm{l}$ of p-nitrophenyl phosphate (p-NPP) $(100 \mathrm{mM})$, the acid phosphatase substrate, and $50 \mu$ of citrate buffer $(0.1 \mathrm{M}, \mathrm{pH}=5)$. The whole is incubated at $37{ }^{\circ} \mathrm{C}$ in a humid atmosphere and $5 \% \mathrm{CO}_{2}$ for $30 \mathrm{~min}$ before $150 \mu \mathrm{l}$ of borate buffer ( $\mathrm{pH} 9.8,0.2 \mathrm{M}$ ) was added to each well, and the absorbance measured at $405 \mathrm{~nm}$. The percentage 
of the activity is determined by the following formula: Activity $(\%)=100 \times(\mathrm{OD}$ sample-OD control $) / \mathrm{OD}$ control [35].

\section{Nitric oxide production}

The amount of NO released by macrophages was measured by determining the amounts of accumulated nitrite $\left(\mathrm{NO}_{2}\right)$ in cell free supernatants via the Griess reaction [36]. In brief, isolated macrophages of each group were incubated for $24 \mathrm{~h}$. Nitrite was then measured by adding $100 \mu \mathrm{l}$ Griess reagent ( $1 \%$ sulfanilamide and $0.1 \%$ naphthylenediamine in $5 \%$ phosphoric acid) to $100 \mu \mathrm{l}$ of harvested culture supernatant. The optical density at $570 \mathrm{~nm}$ $\left(\mathrm{OD}_{570}\right)$ was then measured in a microplate reader (Thermo Scientific, Vantaa, Finland). NO concentrations were calculated by comparison with the $\mathrm{OD}_{570}$ of a standard solution of sodium nitrite diluted in culture medium and placed in parallel wells in the assay plates.

\section{Statistical analysis}

Data were collected and expressed as the mean \pm standard deviation of three independent experiments and analyzed for statistical significance from control. The data were tested for statistical differences by one-way ANOVA followed by student test using statistica. The criterion for significance was set at $P<0.05$.

\section{Abbreviations \\ MeOH: methanol; DMSO: dimethyl sulfoxide; NK: natural killer; CTL: cytotoxic T-lymphocyte; NO: nitric oxide.}

\section{Authors' contributions}

$\mathrm{BJ}$ : was responsible for the conception and design, testing and data acquisition, analysis and data interpretation and drafted the manuscript. CF: made contribution to cellular study. BA: made contribution to experimental animals study. AR: made substantial contribution for important to intellectual content. BBA: made substantial contribution for important to intellectual content. GK: made substantial contribution to conception and revised it critically for important intellectual content. CGL: made substantial contribution to conception and revised it critically for important intellectual content. All authors read and approved the final manuscript.

\section{Author details \\ ${ }^{1}$ Laboratory of Cellular and Molecular Biology, Faculty of Dental Medicine, University of Monastir, Rue Avicenne, Monastir 5000, Tunisia. ${ }^{2}$ Unity of Bioac- tive Natural Substances and Biotechnology, Faculty of Pharmacy, University of Monastir, Rue Avicenne, Monastir 5000, Tunisia. ${ }^{3}$ Higher Institute of Medical Technologies of Tunis, Tunis El Manar University, Tunis Rommana 1068, Tunisia.}

\section{Acknowledgements}

The author acknowledge the "Ministry of Higher Education, Scientific Research and Technology, Tunisia", for the support of this study and also thank.

\section{Compliance with ethical guidelines}

\section{Competing interests}

The authors declare that they have no competing interests.

Received: 22 June 2015 Accepted: 11 August 2015

Published online: 25 August 2015

\section{References}

1. Tucker MA (2009) Melanoma epidemiology. Hematol Oncol Clin N Am 23(3):383-395

2. Poulikakos PI, Rosen N (2011) Mutant BRAF melanomas-dependence and resistance. Cancer Cell 19(1):11-15

3. Parkhurst MR, Riley JP, Robbins PF, Rosenberg SA (2004) Induction of CD4+ Th1 lymphocytes that recognize known and novel class II MHC restricted epitopes from the melanoma antigen gp100 by stimulation with recombinant protein. J Immunother (Hagerstown, Md: 1997) 27(2):79

4. Schietinger A, Greenberg PD (2014) Tolerance and exhaustion: defining mechanisms of T cell dysfunction. Trends Immunol 35(2):51-60

5. Mitchell MS (2003) Immunotherapy as part of combinations for the treatment of cancer. Int Immunopharmacol 3(8):1051-1059

6. Yuan H, Song J, Li X, Li N, Dai J (2006) Immunomodulation and antitumor activity of $\kappa$-carrageenan oligosaccharides. Cancer Lett 243(2):228-234

7. Boubaker J, Bhouri W, Sghaier MB, Bouhlel I, Skandrani I, Ghedira K, Chekir-Ghedira L (2011) Leaf extracts from Nitraria retusa promote cell population growth of human cancer cells by inducing apoptosis. Cancer cell Int 11(1):37

8. Boubaker J, Wissem B, Mohammed BS, Ines B, Mounira K, Ines S, Genviève DFM, Kamel G, Leila C-G (2012) Flavonoids products from Nitraria retusa leaves promote lymphoblastoid cells apoptosis. Nutr Cancer 64(7):1095-1102

9. Franceschi S, Wild CP (2013) Meeting the global demands of epidemiologic transition - the indispensable role of cancer prevention. Mol Oncol 7(1):1-13

10. Martínez C, Yañez J, Rodríguez J, Canteras M, Alcaraz M, Vicente V (2001) Inhibición del crecimiento de la línea de melanoma B16-F10 por diferentes compuestos polifenólicos. Rev Esp Patol 34:317-324

11. Yañez J, Martínez C, Rodríguez J, Canteras M, Alcaraz M, Vicente V (2002) Efecto de seis flavonoides sobre el crecimiento de la línea de melanoma humano SK-MEL-1. Oncologia 25(4):34-214

12. Krifa M, Skandrani I, Pizzi A, Nasr N, Ghedira Z, Mustapha N, Ghedira K, Chekir-Ghedira $L$ (2014) An aqueous extract of Limoniastrum guyonianum gall induces anti-tumor effects in melanoma-injected mice via modulation of the immune response. Food Chem Toxicol 69:76-85

13. Hung K, Hayashi R, Lafond-Walker A, Lowenstein C, Pardoll D, Levitsky $\mathrm{H}$ (1998) The central role of CD4(+) T cells in the antitumor immune response. J Exp Med 188(12):2357-2368

14. Anderson DH, Sawaya MR, Cascio D, Ernst W, Modlin R, Krensky A, Eisenberg D (2003) Granulysin crystal structure and a structure-derived lytic mechanism. J Mol Biol 325(2):355-365

15. Kumar J, Okada S, Clayberger C, Krensky AM (2001) Granulysin: a novel antimicrobial. Expert Opin Investig Drugs 10(2):321-329

16. Varalakshmi C, Ali AM, Pardhasaradhi BV, Srivastava RM, Singh S, Khar A (2008) Immunomodulatory effects of curcumin: in-vivo. Int Immunopharmacol 8(5):688-700

17. Matsunaga K, Klein TW, Friedman H, Yamamoto Y (2002) Epigallocatechin gallate, a potential immunomodulatory agent of tea components, diminishes cigarette smoke condensate-induced suppression of anti-Legionella pneumophila activity and cytokine responses of alveolar macrophages. Clin Diagn Lab Immunol 9(4):864-871

18. López-Posadas R, Ballester I, Abadía-Molina AC, Suárez MD, Zarzuelo A Martínez-Augustin O, de Medina FS (2008) Effect of flavonoids on rat splenocytes, a structure-activity relationship study. Biochem Pharmacol 76(4):495-506

19. Feldman KS, Sahasrabudhe K, Smith RS, Scheuchenzuber WJ (1999) Immunostimulation by plant polyphenols: a relationship between tumor necrosis factor- $\alpha$ production and tannin structure. Bioorg Med Chem Lett 9(7):985-990

20. Rainard P (1986) A colorimetric microassay for opsonins by reduction of NBT in phagocytosing bovine polymorphs. J Immunol Methods 90(2):197-201

21. Tumer C, Bilgin HM, Obay BD, Diken H, Atmaca M, Kelle M (2007) Effect of nitric oxide on phagocytic activity of lipopolysaccharide-induced macrophages: possible role of exogenous L-arginine. Cell Biol Int 31(6):565-569

22. Dong HZT, Peng SM, Li J, Zhang HY (2009) Extraction of sitosterol from hawthorn fruits and effect of sitosterol on immunological function and serum lipid. Nat Prod Res Dev 21:60-63 
23. Limem-Ben Amor I, Boubaker J, Ben Sgaier M, Skandrani I, Bhouri W, Neffati A, Kilani S, Bouhlel I, Ghedira K, Chekir-Ghedira L (2009) Phytochemistry and biological activities of Phlomis species. J Ethnopharmaco 125(2):183-202

24. Sakagami H, Kawazoe Y, Oh-hara T, Kitajima K, Inoue Y, Tanuma S, Ichikawa S, Konno K (1991) Stimulation of human peripheral blood polymorphonuclear cell iodination by lignin-related substances. J Leukoc Biol 49(3):277-282

25. El Abbouyi A, Toumi M, El Hachimi Y, Jossang A (2004) In vitro effects of aqueous seeds extract of Acacia cyanophylla on the opsonized zymosaninduced superoxide anions production by rat polymorphonuclear leukocytes. J Ethnopharmacol 91(1):159-165

26. Klimp A, De Vries E, Scherphof G, Daemen T (2002) A potential role of macrophage activation in the treatment of cancer. Crit Rev Oncol Hematol 44(2):143-161

27. D’Agostini C, Pica F, Febbraro G, Grelli S, Chiavaroli C, Garaci E (2005) Antitumour effect of OM-174 and cyclophosphamide on murine B16 melanoma in different experimental conditions. Int Immunopharmacol 5(7-8):1205-1212

28. Pottier-Alaptite G (1979) Flora of Tunisia, dicotyledonous angiosperm-apetalous-ialpetaes

29. Cheib MBM (1998) Flora succint and illustrated flora of the arid zone and Sahara of Tunisia
30. Boubaker J, Skandrani I, Bouhlel I, Ben Sghaier M, Neffati A, Ghedira K, Chekir-Ghedira L (2010) Mutagenic, antimutagenic and antioxidant potency of leaf extracts from Nitraria retusa. Food Chem Toxicol 48(8-9):2283-2290

31. Carmichael J, DeGraff WG, Gazdar AF, Minna JD, Mitchell JB (1987) Evaluation of a tetrazolium-based semiautomated colorimetric assay: assessment of chemosensitivity testing. Cancer Res 47(4):936-942

32. Geran RI (1972) Protocols for screening chemical agents and natural products against animal tumors and other biological systems. Cancer Chemother Rep 3:51-61

33. Manosroi A, Saraphanchotiwitthaya A, Manosroi J (2003) Immunomodulatory activities of Clausena excavata Burm. f. wood extracts. J Ethnopharmacol 89(1):155-160

34. Sarangi I, Ghosh D, Bhutia SK, Mallick SK, Maiti TK (2006) Anti-tumor and immunomodulating effects of Pleurotus ostreatus mycelia-derived proteoglycans. Int Immunopharmacol 6(8):1287-1297

35. Manosroi A, Saraphanchotiwitthaya A, Manosroi J (2005) In vitro immunomodulatory effect of Pouteria cambodiana (Pierre ex Dubard) Baehni extract. J Ethnopharmacol 101(1):90-94

36. Green LC, Wagner DA, Glogowski J, Skipper PL, Wishnok JS, Tannenbaum SR (1982) Analysis of nitrate, nitrite, and [15 N] nitrate in biological fluids. Anal Biochem 126(1):131-138

\section{Submit your next manuscript to BioMed Central and take full advantage of:}

- Convenient online submission

- Thorough peer review

- No space constraints or color figure charges

- Immediate publication on acceptance

- Inclusion in PubMed, CAS, Scopus and Google Scholar

- Research which is freely available for redistribution

Submit your manuscript at

www.biomedcentral.com/submit

C Biomed Central 